\title{
A Study on Torque Rich Phenomena in Ship Operation
}

\author{
Dang Van Uy \\ Marine Engineering Department, Vietnam Maritime University, Haiphong City 180000, Vietnam
}

\begin{abstract}
The "torque rich" is known as a phenomenon that makes reduction of ship speed, overload for main engine and higher fuel consumption of ship, even can cause some major problems for a ship propulsion system. In Vietnam, according to investigated results, almost ships of country merchant fleet are facing with ship speed decrease, fuel consumption increase due to the torque rich, consequently the average ship operation cost is increasing from $15 \%$ to $25 \%$, even higher in some cases and the environment is badly impacted. To comply with the international requirements and national legislation regarding to "using efficiently energy and environment protection", Vietnamese shipping companies must combat with the torque rich problem as crucial reason making downgrade in ship operation. The article shows a potential method to reduce the torque rich phenomena by modifying propeller which has been successfully applied for a real ship in Vietnam.
\end{abstract}

Key words: Torque rich, energy, propeller, diesel engine.

\section{Introduction}

Using efficiently energy in order to save fuel on board ships is a long term objective in worldwide scale due to the environment protection and the limitation of energy natural resources. The International Maritime Organization has already issued some international conventions concerning with the saving fuels and limitation of discharge of the toxic gases to the atmosphere. In Annex VI, MARPOL 73/78, there are some guiding methods that support the ship designers and the ship operators using fuel more efficiently such as EEDI, EEOI and SEEMP are, however, not enough to undergo the goal "how to minimize fuel consumption for a voyage" [4].

As known, during ship operation time, there are some existing problems that make ships cost more fuel and among them it is the unbalance of energy between a main engine and a propeller. The unbalanced energy is normally formed by reducing of a main engine power and increasing required power of a propeller. The reason influencing on the power reduction of a main engine is mainly aging of the all

Corresponding author: Dang Van Uy, Ph.D., professor, research fields: maritime engineering sciences and ship's technology. components of a diesel engine, though the diesel engine is under strictly maintenance plan. According to some statistics, any diesel engine after 5 years period of operation, it can lose about $5 \%$ of its power and after 10 years the power loss can reach as much as $13 \%$ to $15 \%$ and even more $[2,12]$. Meanwhile, the resistance of ship hulls and propellers is much more increased due to their shape deformation, marine growth and so on.

Therefore the higher ship age is, the lager the energy unbalance between a main engine and a propeller is. This phenomenon of the energy unbalance of a ship is so called over-torque for a driving diesel engine or a torque rich of a diesel engine.

Operating a ship in the torque rich condition for main diesel engine will cost fuel consumption much higher than that of a ship in normal condition. Moreover, a diesel engine in torque rich condition will work seemingly hard and discharge black smoke to the environment that is a reason to pollute the natural air due to the smoke containing a lot of toxic gases such as $\mathrm{NO}_{\mathrm{x}}, \mathrm{SO}_{\mathrm{x}}, \mathrm{CO}$ and $\mathrm{HC}$. So, to improve the technical condition of aging ships, there must combat the unexpected torque rich of a diesel engine equipped on board a ship. 


\section{A Concept of Diesel Engine Torque Rich}

The overload in connection with the torque of a diesel engine is not new idea and experts also named as a torque rich of main diesel engines. The scientific concept of diesel engine torque rich is energy unbalance between a driving diesel engine and ship hull and propeller. The torque rich can be occurred during ship operation due to some reasons as follows:

- Bad weather conditions such as a storm, ice, etc.;

- Narrow channel where a ship is navigating;

- Deterioration of the performance by aging of main engine, hull and propeller (aging ships) [2, 7].

Among them, the third reason is very important for vessels under operation upon strong impacts on speed and fuel consumption of a ship.

In practice, the torque rich due to the third reason can be found in a ship over 7 to 8 years old and sometimes also in a newly built ship that has been wrongly designed. The torque rich depends on power generated by a driving diesel engine and power required by hull, propeller of a ship. The driving diesel engine is found in power decrease due to all its components getting aged by operation times and tendency of diesel engine power decrease is showed in Fig. 1 [2].

Research results showed that in the beginning, a new diesel engine has a power $\mathrm{N}_{0}$ (highest value), after some years of operation, the power of the engine is decreased to value $\mathrm{N}_{1}\left(\mathrm{~N}_{1}<\mathrm{N}_{0}\right)$ and the engine needs to be maintained in order to recover its capacity, however, the power of the engine cannot reach the same value as original one, but just only $\mathrm{N}_{01}$ lower than N0. The process will be repeated in whole life of a diesel engine. The phenomenon of the power decrease is named as natural decrease of power of diesel engines. Such power decrease is always associated with two specific features as follows:

- An ability of power recover is decreasing from first maintenance period to next ones;

- And, time between two maintenance periods is shorter step by step.
According to statistic results of some diesel makers and diesel engine operators, there can sum that: within a period from 5 to 7 years counting from the first time since a diesel engine has been putting into operation, the engine power decrease can be estimated from $3 \%$ to $5 \%$, then the power decrease shall be from $10 \%$ to $15 \%$ or even higher. Some experimental results of diesel engine power decrease due to operation time of some engine makers such as MAN B\&W, Sulzer, Warsilla, Mitsubishi, as mentioned in Table 1 $[5,6,14]$.

Nevertheless, ship hull and propeller require power in adverse tendency following their aging. With years to elapse, resistance of ship hull and propeller is increased considerably. The reasons that make the resistance increased are marine growth and bends on the hull and the propeller during operation in different seawater territories. Though, the marine growths can be removed well by cleaning the hull and the propeller during docking, but the bends of hull and propeller are not easy to be treated to recover their technical condition as before. For this reason, considerably large additional resistance of hull and propeller still is remained on ships in service compared with their new states. Consequently, the advance speed (Va) and the efficiency of propeller will be smaller. That is, the wake fraction $(\mathrm{w})$ becomes large and the speed of ship becomes slower [12].

In the operation process, to help operators more clearly understand about the overload applied for driving diesel engines, the torque rich phenomenon can also be presented by characteristics as shown in Fig. 2.

Regarding to driving diesel engine (main engine), an operating power zone is limited by area DCBAA'

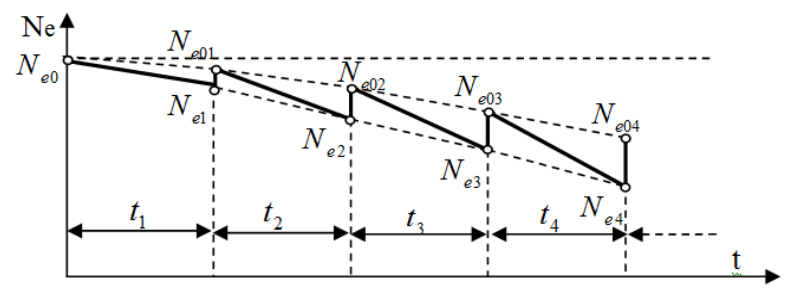

Fig. 1 Natural decrease of diesel engine power. 
Table 1 Estimated decrease of diesel engine power in operation time.

\begin{tabular}{llllll}
\hline & \multicolumn{5}{c}{ Operation time [years] } \\
\cline { 2 - 6 } & 5 & 10 & 15 & 20 & 25 \\
\hline $\begin{array}{l}\text { Decrease of } \\
\text { power [\%] }\end{array}$ & 3 & $5-7$ & $8-10$ & $12-15$ & $15-20$ \\
\hline
\end{tabular}

and horizontal axis (n). The operating power zone can be changed in tendency of decrease during a ship operation. The resistance characteristic of ship hull and propeller is presented by ki that $\mathrm{k}_{1}$ for new hull and propeller of ship; $\mathrm{k}_{2}$ for ship bollard test; $\mathrm{k}_{3}$ for so called "light propeller" and $\mathrm{k}_{4}$ stands for heavy propeller.

Now, suppose that a new ship is operating with characteristic $\mathrm{k}_{1}$ and working point between driving diesel engine and hull, propeller is AO. However, when the ship sailing in severe weather conditions or when the ship getting aged, then the ship is supposed to work with a heavy propeller as illustrated by $\mathrm{k}_{4}$. If so, working point between driving diesel engine and propeller is $A_{01}$, then ship speed is decreased or in case of keeping same speed, the working point also will be $\mathrm{A}_{03}$ and driving diesel engine will be overloaded (torque rich).

It is applied to Vietnamese merchant fleet, data from Vietnam Maritime Bureau show that ship main engines of Vietnamese fleet are 4-stroke or 2-stroke diesel engines with output from $3,000 \mathrm{~kW}$ to 7,000 $\mathrm{kW}$, among them there are $65 \%$ of 2 -stroke diesel engines and $35 \%$ of 4 -stroke ones. Our investigation about utilization of main engine power gives statistical results that almost main engines are able to generate power only from $50 \%$ to $75 \%$ of its nominal value at revolution from $72 \%$ to $93 \%$ of nominal revolution. Statistic data are presented in Fig. 3 [13, 15].

So, on a base of the investigation results of Vietnamese fleet, we can conclude that the power generated by the main engines of ships is much lower than the original nominal power. Therefore, almost main engines are operated at shaft speed much lower than original, if let the main engines be operated at higher or same original speed, the torque rich will firmly be occurred.

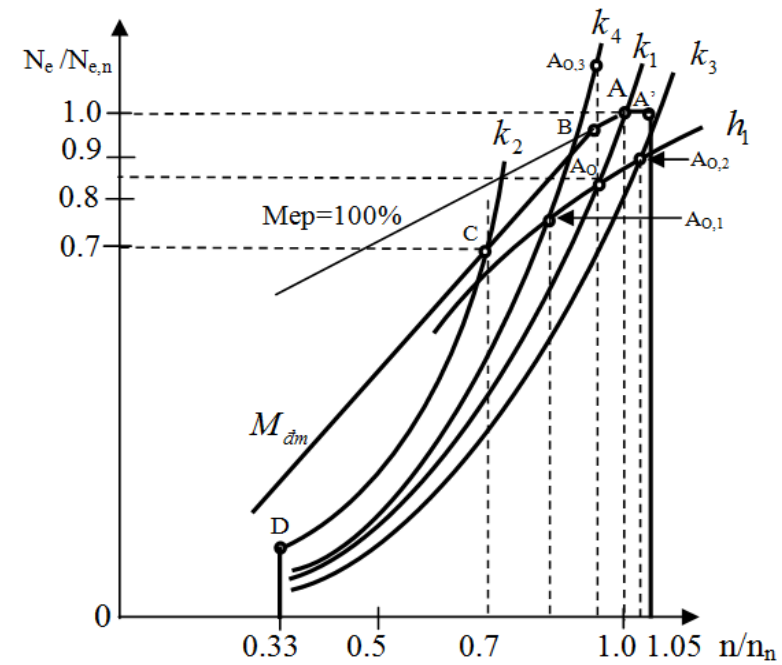

Fig. 2 Illustration of torque rich of ship propulsion system.

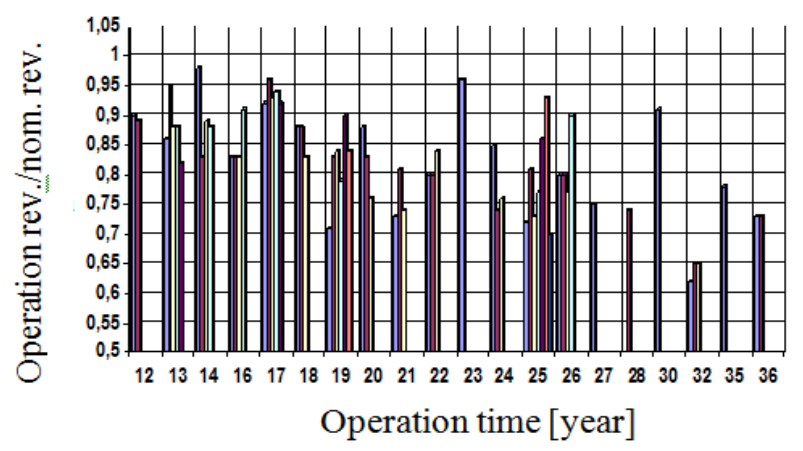

Fig. 3 Statistic data of power decrease due to aging.

\section{Proposed Method of Torque Rich Treatment}

Torque rich of diesel engines results in many worst cases such as:

- Decreasing general efficiency of ship propulsion system;

- Increasing fuel consumption of driving diesel engines and also daily expenditure of ships;

- Shortening life of ship propulsion system and even damaging driving diesel engines, some other equipment;

- Causing pollution to the environment.

Therefore, there definitely needs some know-how to iron out the torque rich occurred at ship propulsion system. However, the temporary torque rich as mentioned above is not necessary to take into account, 
there will only take the torque rich due to ship aging into consideration.

\subsection{Identification of Torque Rich Occurrence}

As well known, the torque rich occurred due to ship aging is happened naturally. On board ships, the torque rich can be easily detected, however to evaluate a level of torque rich is rather difficult. Based on conditions during ship operation, the torque rich can be identified by some main signs as follows [2, 14, 15]:

- Level of fuel rack higher than normal;

- High temperature of exhaust gas at all cylinders and some times, black color of exhaust gas existing;

- Lower speed of ship.

To evaluate a level of torque rich, we need to apply several steps, from evaluation of actual power of driving diesel engine to estimate resistance of hull and power required by propeller at its present technical condition. The evaluation of torque rich is normally carried out at shore side in ship repair yards with using some special tools and this matter will be described in next item.

\subsection{Selection of Torque Rich Treatment Method}

As mentioned, ship getting aged and triangle interaction between driving engine, hull and propeller are performing the overload or torque rich for the driving engine. Therefore, to treat the torque rich, all elements need to be done. However, in practice experts showed that to recover the driving engines and hulls into original technical state is impossible due to limitation of budget investment, so the only way to help treating the torque rich is propeller modification. At present time, there are several know-how recommended to modify ship propeller in order to treat torque rich such as $[5,12]$ :

- Wash-back modification on trailing edge side of propeller blade. Basic idea of this method is that to cut slightly and shape the trailing edge side of propeller blades, the effective pitch of propeller will be decreased, consequently the propeller becomes lighter and requires smaller power matched to the driving engine. The method can give $4 \%$ increasing of propeller revolution;

- Method of propeller diameter cutting. The method based on idea of reducing an area of propeller blades, simultaneously its pitch ratio is decreased. Consequently, propeller power required will be adjusted suitably to prime diesel engine. After execution, the propeller speed will be increased at the same output absorbed in comparison with the original propeller;

- Twisting propeller blades. The idea of this method is based on twisting technology of propeller blades to modify pitch of actual propeller somehow to be suitable to prime diesel engine. The method is usually adopted in Europe and can help the propeller shaft speed gain as much as $5 \%$. Disadvantage of this method is requiring complex works and high cost.

As looked at the above mentioned methods to treat the torque rich, the method by wash-back modification on the trailing edge side of the propeller blades are much more practical due to less workability and more economy and effectiveness.

\subsection{Propeller Modification Procedures}

The modification of ship propeller must be carried out in several complex stages as shown in Fig. 4.

On a base of the modification stages mentioned in Fig. 4, a procedure of ship propeller modification can be processed as follows:

Stage 1: Check and primary evaluation of propeller.

Stage 2: Installing and calibrating of measurement tool.

Stage 3: Taking measurement of the main technical parameters of a propeller. The aim is to confirm a "heaviness level" of a propeller in accordance with its actual need. The measurement is carried out on base of a "net" that is built for every propeller blade. The net is created by divided angles for each blade $\alpha=$ $3,600 / \mathrm{i}$ ( $\mathrm{i}=$ amount of blades). The net is as shown in Fig. 5 and the measurement will be taken from propeller 


\begin{tabular}{l|l|}
$\begin{array}{l}\text { Torque rich } \\
\text { identification }\end{array}$ & $\begin{array}{l}\text { Calculation of } \\
\text { modification level }\end{array}$
\end{tabular}$\rightarrow \begin{aligned} & \text { Carrying out } \\
& \text { modification }\end{aligned} \rightarrow \begin{aligned} & \text { Final evaluation after } \\
& \text { propeller modification }\end{aligned}$

Fig. 4 General procedure of propeller modification.

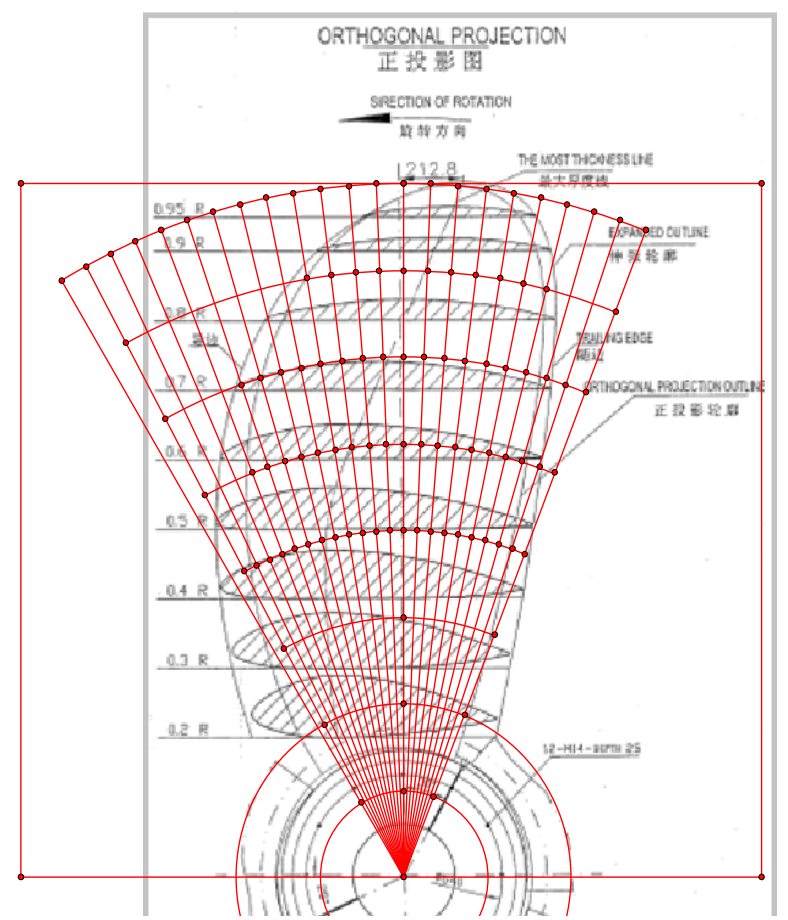

Fig. 5 The created net for measurement of propeller parameters.

hub (center) to the top of blade in several steps: $0.6 \mathrm{R}$, 0.7R, 0.8R, 0.9R and 0.95R.

Stage 4. Calculation of propeller modification level. We must use Papmiel characteristic to find out suitable technical parameters of actual propeller which can be fitted to new capacity of a driving diesel engine as shown in Fig. 6.

Calculation of proper technical parameters of actual propeller such as diameter, stroke ratio and blades area ratio is based on supposing ship speed (V) and propeller shaft revolution (n). In case of using Papmiel characteristic to calculate optimum parameters of propeller, there needs applying two well-known formulas presenting thrust and advance coefficients of propeller $[3,7]$ :

$$
K_{T}=\frac{T}{\rho \cdot n^{2} \cdot D^{4}} ; J=\frac{V}{n \cdot D}
$$

Now, let take supporting coefficient named $K_{n}$ and $K_{n}=\frac{n^{2} T}{\rho V^{4}}$, so relationship between $\mathrm{K}_{\mathrm{n}}$ and $\mathrm{K}_{\mathrm{T}}$ as follow:

$$
K_{T}=K_{n} \times J^{4}
$$

It is very convenient that coefficient $K_{n}$ can be complied with requirement that technical parameters of propeller can be calculated from supposed variables (n, $T, V, \rho)$ and $K_{n}$ does not contain propeller diameter (D).

In Fig. 6 there are 5 lines of $\mathrm{K}_{\mathrm{T}}$ appropriate to 5 different values of H/D $(0.6 ; 0.8 ; 1.0 ; 1.2$ and 1.40 and named by function as $K_{T}=\mathrm{f}(\mathrm{H} / \mathrm{D} ; \mathrm{J})$. There also can find line presenting for $\mathrm{K}_{\mathrm{T}}$ (formula 2) named as $K_{T}=f(T)$ is cutting lines $K_{T}=f(H / D ; J)$ at some points

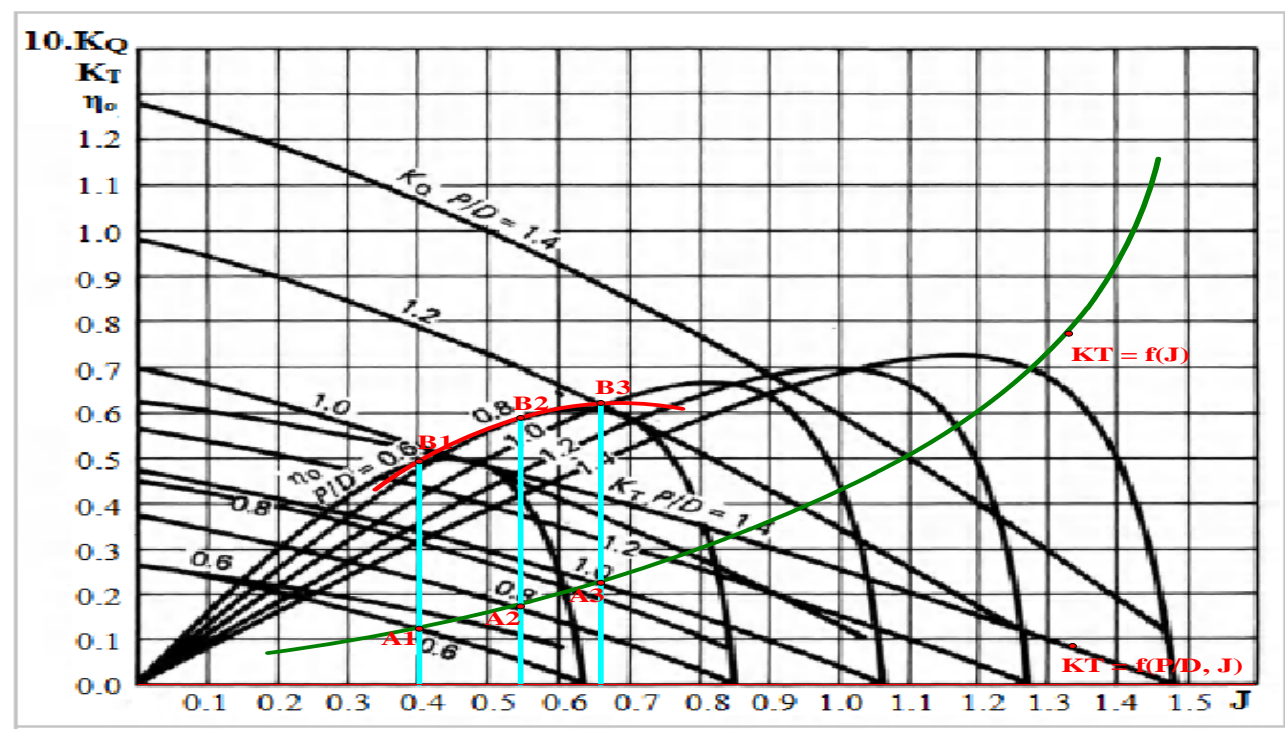

Fig. 6 Calculation proper technical parameters of propeller. 
indicated by $\mathrm{A}_{1}(\mathrm{H} / \mathrm{D}=0.6), \mathrm{A}_{2}(\mathrm{H} / \mathrm{D}=0.8), \mathrm{A}_{3}(\mathrm{H} / \mathrm{D}$ $=1.0)$ and so on. On the propeller efficiency characteristic $[\eta=f(J)]$, there are several points $B_{i}\left(B_{1}\right.$ to $B_{3}$ ) formed by perpendicular lines from points $A_{i}$ to axis $J$. Then, let connect all the points $B_{i}$ together to form a line that can be utilized to optimize the technical parameters of propeller by two solutions:

- to select optimum point located on the line $\mathrm{B}_{\mathrm{i}}$; or

- to make a line going through all the maximum point on all the efficiency characteristics and names as $\eta_{\max }$, then let select optimum point that is a section between line $\eta_{\max }$ and line $\mathrm{B}_{\mathrm{i}}$.

Practical application showed that the two solutions give a very similar result, however the first solution is much more simple. So, on a base of the optimum point on line $\mathrm{B}_{\mathrm{i}}$ and optimum value of $\mathrm{J}$, an optimum diameter of propeller can calculated as:

$$
D_{\text {opt }}=\frac{V}{n \cdot J_{\text {opt }}}
$$

All optimum data of an actual propeller can be solved by using Excel program and then new characteristic of propeller can be built.

Stage 5. Carrying out the washback on trailing edge side of propeller blade. A propeller blade washback must be made by using so called "cold work" and a suitable tool is portable granding machine.

Stage 6. Checking technical parameters of propeller after modification. There are 3 most important propeller parameters that must be checked carefully such as: diameter, stroke coefficient (H/D) and area coefficient $\left(\mathrm{A} / \mathrm{A}_{0}\right)$.

Stage 7. Propeller static balancing.

Stage 8 . Completion work and propeller back to a ship.

\section{Practical Application}

To comply with IMO and national requirements on fuel saving and air pollution limitation from ships, many shipping companies in Vietnam are following up solution of propeller modification. Our research has been carried out for one tanker shipping company as pilot company having willing to apply the know-how to modify ship propeller.

\subsection{Briefly History}

The tanker shipping company is named as KHAIHOAN Marine Corp. having a headquarter in Hochiminh City. The company owns several tankers and among them two ships named Glory Star and Glory Ocean had some problems with propulsion system such as high temperatures of exhaust gas of main engines, ship speed decrease, higher fuel consumption, even the propeller shaft of Glory Star was deformated during the ship sailing from Indonesia to Vietnam.

The investigation results as in Fig. 3 showed that almost ships which are operating in Vietnam are under torque rich pressure. There is no statistics about using fuel oil yearly, but it is sure that not small amount of fuel oil lost due to main diesel engines overloaded during operation.

\subsection{Propeller Modification and Results}

Modification work has been made for two ships and the mentioned 8-stage procedure has been applied to modify propellers of the ships. However, there was primary predict that the torque rich was found seriously and slightly on Glory Star and Ocean Star respectively. Therefore, the propeller of Glory Star must be more carefully checked and need major modification.

Regarding to the propeller of Glory Star, after carrying out stage 3 of the above mentioned modification procedure, the measurement data are listed in Table 2.

So, it can realize that the stroke ratio of the actual

Table 2 Technical data of propeller.

\begin{tabular}{|c|c|c|c|}
\hline \multicolumn{4}{|l|}{ Glory Star Propeller } \\
\hline Main technical data & Design & Measurement & Difference \\
\hline $\begin{array}{l}\text { Propeller stroke } \\
{[\mathrm{mm}]}\end{array}$ & 3,026 & 3,095 & \\
\hline Stroke ratio & 0.6905 & 0.7062 & $2.27 \%$ \\
\hline
\end{tabular}


propeller is $2.27 \%$ higher than design ratio. Therefore, the actual propeller is heavy for the driving diesel engine even when the ship was on very first maiden voyage and it is no doubtful that the torque rich has happened for the aging ship. The next stage is to identify a possible level of torque rich for the main engine and a level of modification for the mentioned propeller. To do so, there must use the measurement data and principle formulas such as $\mathrm{K}_{\mathrm{Q}}, \mathrm{K}_{\mathrm{T}}, \mathrm{J}, \eta$ and the Pampmiel characteristic including the procedure to calculate optimization parameters of the actual propeller is showed in Fig. 7.

In practice, there are several combinations of propeller optimization parameters depending on operation speed of a ship and a main engine revolution. For Glory Star, following with proposal from the shipowner, there presented 4 combinations of propeller optimization parameters as follows:

First choice: Main engine revolution: $470 \mathrm{rpm}$ (propeller shaft: $133.5 \mathrm{rpm}$ ), ship speed: 11.8 knots; the washback of propeller blades will be started from point of $0.5 \mathrm{R}$ and going around the top of blades. So, washback estimation for the propeller blades is calculated as shown in Table 3.

Second choice: the main engine: $472 \mathrm{rpm}$ (propeller shaft: $134 \mathrm{rpm}$ ), ship speed: 12.4 knots; the washback of propeller blades will be started from point of $0.5 \mathrm{R}$ and going around blades top. So, washback estimation of the propeller blades is calculated as shown in Table 4.

Summary: After taking the 2 choices into consideration, there can result in conclusion that radius

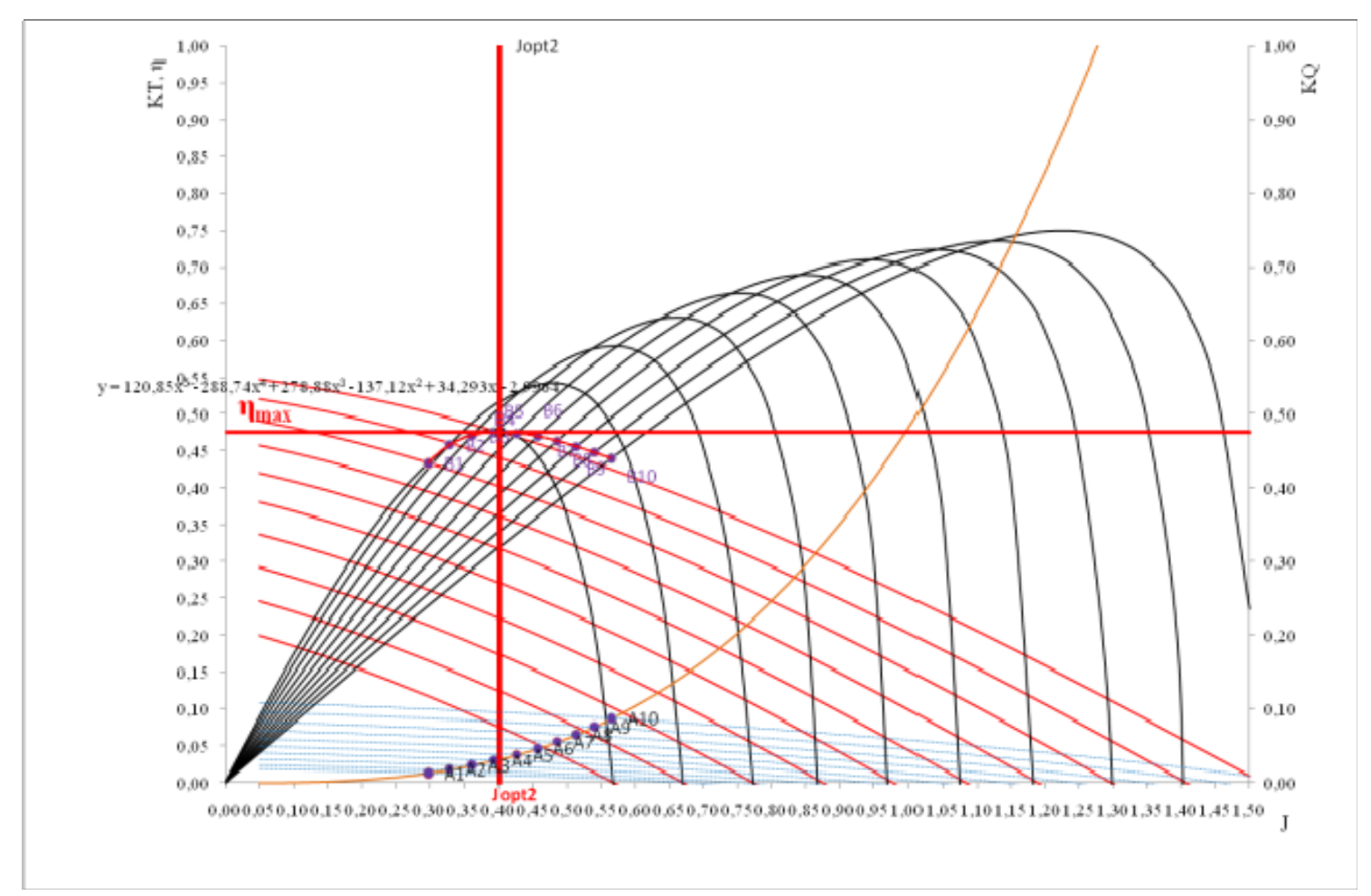

Fig. 7 Papmiel characteristic and propeller optimization parameters.

Table 3 Estimation of blade edge washback $(n=470 \mathrm{rpm}, \mathrm{V}=11.8)$.

\begin{tabular}{lllll}
\hline No & Optimum diameter & Diameter cut & Reduction of a blade area & Average amount of egde washback \\
\hline 1 & $\mathrm{D}_{\text {opt }}[\mathrm{cm}]$ & $\delta \mathrm{D}[\mathrm{cm})$ & $\delta \mathrm{E}_{\mathrm{e}}\left(\mathrm{cm}^{2}\right)$ & $\delta \mathrm{B}(\mathrm{cm})$ \\
2 & 429.00 & 9.00 & 655 & 7.28 \\
3 & 435.00 & 3.00 & 220 & 2.44 \\
\hline
\end{tabular}


Table 4 Estimation of blade edge washback $(n=472, V=12.4)$.

\begin{tabular}{lllll}
\hline No & Optimum diameter & Diameter cut & Reduction of a blade area & Average amount of egde washback \\
\hline & $\mathrm{D}_{\text {opt }}[\mathrm{cm}]$ & $\delta \mathrm{D}[\mathrm{cm})$ & $\delta \mathrm{E}_{\mathrm{e}}\left(\mathrm{cm}^{2}\right)$ & $\delta \mathrm{B}(\mathrm{cm})$ \\
\hline 1 & 431.00 & 7.00 & 511 & 5.68 \\
2 & 435.00 & 3.00 & 220 & 2.44 \\
3 & 438.00 & 0 & 0 & 0 \\
\hline
\end{tabular}

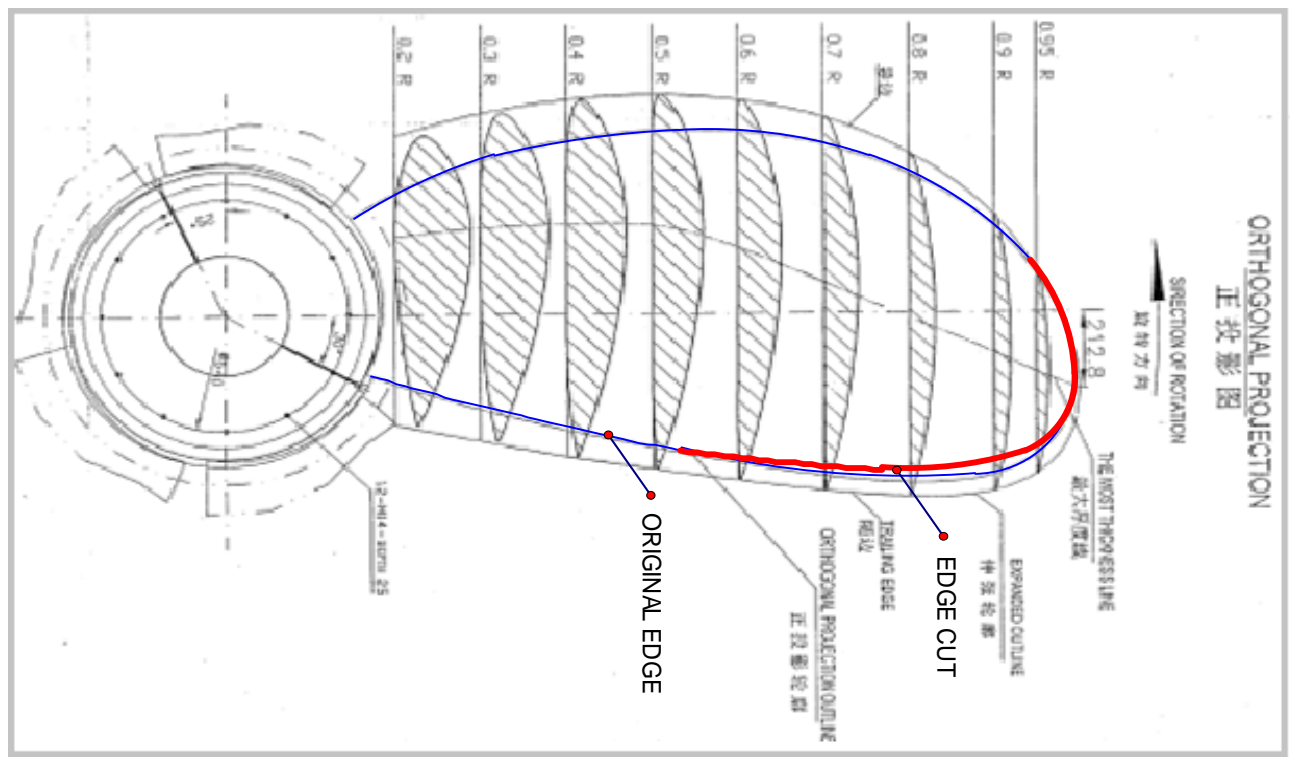

Fig. 8 The edge washback sketch.

of each blade of the actual propeller will be cut from $20 \mathrm{~mm}$ to $30 \mathrm{~mm}$ and the edge of each blade will be washback in length of $100-110 \mathrm{~mm}$, in width from 70 $\mathrm{mm}$ (near to top of blade) to $30 \mathrm{~mm}$ (near to hub of propeller). Besides these, the blade ratio of the actual propeller should be kept as the original value $\mathrm{Ae} / \mathrm{Ao}=$ 0.535 after complete modification of the propeller. A sketch of propeller edge washback is presented in Fig. 8.

The washback of the propeller blade edge has been carried out in Saigon Shipmarine Yard by cold work with support of grinding machine and other necessary tools. The job has been done perfectly, then the propeller was sent to static balance check. Finally, the propeller was installed for Glory Star for modification work completion.

As mentioned above, in a case of Glory Ocean ship, the torque rich is lightly occurred, therefore the propeller of Glory Ocean has been checked and planned to be modified as shown in Fig. 9.
A main work that must be done here is to grind the surface of the propeller blades in an area with length from $0.5 \mathrm{R}$ to $0.90 \mathrm{R}$ and width from trailing edge to middle of blades. The amount must be grinded in depth about $1.0 \mathrm{~mm}$ in the whole area. An aim of grinding the blade surface of propeller is to increase the propeller efficiency and consequently to reduce main engine fuel consumption.

\section{Test Result after Propeller Modification}

To confirm an effect of propeller modification for two ships, the ships have been tested when they were sent for maiden voyage after finishing dry dock. The two vessels were built in China and bought by KHAIHOAN Marine Corp. in 2007. They are oil product tankers having technical data shown in Table 5 .

(1) Ship "Glory Star"

Glory Star has sailed under ballast condition from Vungtau City to Dungquat Port in distance about 350 


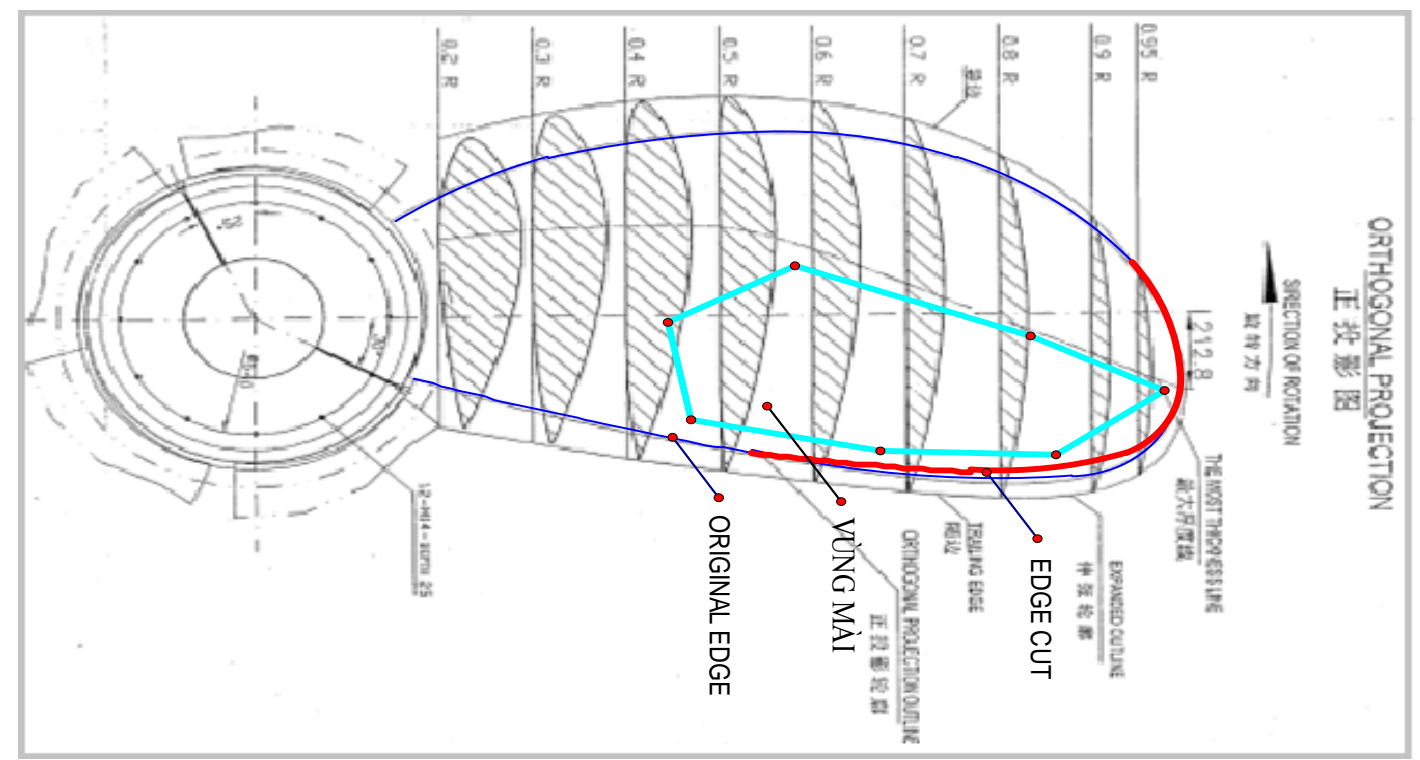

Fig. 9 The plan to modify propeller of Glory Ocean ship.

Table 5 Technical data of Glory Star and Glory Ocean.

\begin{tabular}{lll}
\hline Technical data & \multicolumn{2}{c}{ Ship } \\
\cline { 2 - 3 } & Glory Star & Glory Ocean \\
\hline Tonnage [DWT] & 16,800 & 12,806 \\
Total length [m] & 142.5 & 134.85 \\
Breadth [m] & 23 & 22.0 \\
Draft [m] & 12.6 & 10.6 \\
Ship speed [knot] & 13 & 13.5 \\
Main engine & $8 \mathrm{PC} 2-6,4$-stroke & 8 PC2-6/2L, 4-stroke \\
Max. output [kW] & 4,400 & 4,400 \\
Max. revolution [rpm] & 500 & 520 \\
Fixed propeller & 01 & 01 \\
Diameter [m] & 4.382 & 3.880 \\
Number of blades & 05 & 05 \\
Stoke ratio [H/D] & 0.691 & 0.694 \\
Area ratio of blades & 0.535 & 0.577 \\
Weight [kg] & 7,327 & - \\
Working revolution [rpm] & 135 & 177.3 \\
Reduction gear ratio & 3.52 & 3.0 \\
\hline
\end{tabular}

miles and then she came back to Vungtau City in December, 2012. Sea conditions from Vungtau City to DungQuat Port and back are moderate with wind SE4/SE3, no current. During voyage, test has been carried out with measuring the main engine average fuel consumption, main engine revolution, ship speed and so on. The test results are shown in Table 6. From the data in Table 5, there can sum that at similar operation conditions (weather, ship load) the fuel consumption of the main engine is saved about $16.5 \%$ compared with that before modification of ship propeller.

\section{(2) Ship "Glory Ocean"}

Glory Ocean was allowed to be on sea trial in July, 2015 after her propeller modification. Glory Star has been on a trip from Saigon Port to Quinhon Port with distance about 400 miles. The test was carried out on board ship and test results are presented in Table 6 . The 
Table 6 Test results after propeller modifications.

\begin{tabular}{|c|c|c|c|c|c|c|c|c|c|c|}
\hline \multirow[b]{2}{*}{ Ship } & \multicolumn{5}{|c|}{ Before propeller modification } & \multicolumn{5}{|c|}{ After propeller modification } \\
\hline & $\mathrm{FO}[\mathrm{T} / \mathrm{d}]$ & $\begin{array}{l}\text { Exh. gas } \\
\text { temp }\left[{ }^{0} \mathrm{C}\right]\end{array}$ & $\begin{array}{l}\text { Fuel rack } \\
\text { position }\end{array}$ & $\begin{array}{l}\text { Main engine } \\
\text { speed [rpm] }\end{array}$ & $\begin{array}{l}\text { Ship speed } \\
\text { [knots] }\end{array}$ & $\mathrm{FO}[\mathrm{T} / \mathrm{d}]$ & $\begin{array}{l}\text { Exh. gas } \\
\text { temp }\left[{ }^{0} \mathrm{C}\right]\end{array}$ & $\begin{array}{l}\text { Fuel rack } \\
\text { position }\end{array}$ & $\begin{array}{l}\text { Main engine } \\
\text { speed [rpm] }\end{array}$ & $\begin{array}{l}\text { Ship speed } \\
\text { [knots] }\end{array}$ \\
\hline \multicolumn{11}{|c|}{ Propeller test results of Glory Star } \\
\hline Ballast & 17.1 & 458 & 37.2 & 472 & 12.0 & 14.3 & 460 & 33.4 & 472 & 11.8 \\
\hline Full cargo & 17.6 & 466 & 39.0 & 472 & 11.4 & 14.7 & 463 & 34.2 & 472 & 11.8 \\
\hline Full cargo & & & & & & 15.1 & 464 & 34.5 & 473 & 12.1 \\
\hline \multicolumn{11}{|c|}{ Propeller test results of Glory Ocean } \\
\hline Ballast & 14.5 & 450 & 30.2 & 472 & 13.1 & 13.6 & 402 & 28.7 & 472 & 13.4 \\
\hline Full cargo & 15.3 & 455 & 34.6 & 472 & 13.2 & 14.2 & 430 & 32.6 & 472 & 13.4 \\
\hline
\end{tabular}

test results of Glory Ocean showed that the fuel consumption of main engine is about $6-7 \%$ less than that before modification of the ship propeller. The less amount of fuel saved in Glory Ocean case due to original design of Glory Ocean was more precise in comparison with Glory Star.

\section{Conclusions}

Ship aging is natural phenomenon that becomes main reasons to make an energy unbalance between a driving engine (main engine) and hull, propeller or so called "torque rich" of main engines in many cases during ship operation. The above mentioned method to modify propellers of the aging ships through 8 stages has brought back effectively the balance of energy to a propulsion system of ship and solved mainly the decrease of ship speed, increase of fuel consumption and other related technical problems of a propulsion system. So, there can sum that:

- The aging ship is always associating with the torque rich phenomenon which is a main reason to decrease ship speed, increase fuel consumption and commonly to downgrade ship operation;

- The torque rich is not difficult to be identified and it can be treated by using the mentioned 8-stage method to modify a propeller of ship;

- After modifying ship propeller, there can save as much as $20 \%$ of fuel consumption while speed of ship is slightly reduced;

- The propeller modification method can be applied repeatedly for same propeller during ship in dry dock for periodical classification survey of hull. The method also gives good result with low cost and short working time.

In general, there can say that the mentioned propeller modification method is suitable choice for Vietnamese shipping companies to treat the torque rich for main engines of ships. The method does not need high investment cost, but can give more efficiency for ship operation and simultaneously contribute a significant role in the environment protection.

\section{References}

[1] ABB Automation Products. The Solution to Your Torque Measuring Needs. Sweden, 206.

[2] Dang Van Uy and Research Group. 2015. "To Propose Technical and Managerial Solutions to Reduce Fuel Consumption on Board Ship: Be Applied for One Merchant Fleet." National Energy Saving Program, Project of Fuel Consumption Reduction, Hanoi.

[3] Kristensen, H. O., and Lutzen, M. 2012. Prediction of Resistance and Propulsion Power of Ships. Denmark.

[4] IMO Resolution MEPC 213(63). 2012. "Guidelines for the Development of a Ship Energy Efficiency Management Plan (SEEMP)."

[5] Japan Diesel Engine Testing Data (IHI, TUMM, MITSUI).

[6] Kawasaki Heavy Industries. Kobelco Marine Eng.; Kamome Propeller Co., Ltd. Yokohama (Japan marine journals).

[7] Charchulski, K., and Gorski, Z. 1979. Podstawy eksploatacji napedow statkow morskich. Gdynia, Poland.

[8] Kongsberg Maritime AS. 2013. Ship Performance System, Norway.

[9] Mads, A.-H. 2010. "Monitoring of Hull Condition of 
Ships.” M.Sc. thesis, Norwegian University of Science and Technology.

[10] MAN Diesel \& Turbo. 2013. Basic Principles of Ship Propulsion. Denmark.

[11] Moody, R. 1996. Preliminary Power Prediction during Early Design Stages of a Ship. Cape Town, South Africa.

[12] Propeller and Shafting Committee [Japan]. 1992. "Propeller Modification for Recovery of Decreased
Propeller Shaft Speed.” Bulletin of the M.E.S.J. 20 (2).

[13] Prime Minister. 2014. Plan for Shipping Development in Vietnam forward to 2020 and Vision to 2030.

[14] Borkowski, T., Kowalak, P., and Myskow, J. 2012. Vessel Main Propulsion Engine Performance Evaluation. Szczecin, Poland.

[15] Technical Data (Noon report, Voyage report) from Vietnamese Shipping Companies: VOSCO, EDSCO, FALCON, PTSC, PVTRANS, VITACO. 